\title{
Pertumbuhan Penduduk Perkotaan dan Perkembangan Pola Distribusinya pada Kawasan Metropolitan Surakarta
}

\author{
Fadjar Hari Mardiansjah' \\ Departemen Perencanaan Wilayah dan Kota \\ Universitas Diponegoro, Semarang, Indonesia \\ Wiwandari Handayani \\ Departemen Perencanaan Wilayah dan Kota \\ Universitas Diponegoro, Semarang, Indonesia
}

\author{
Jawoto Sih Setyono \\ Departemen Perencanaan Wilayah dan Kota \\ Universitas Diponegoro, Semarang, Indonesia
}

Artikel Masuk : 9 Agustus 2018

Artikel Diterima : 14 November 2018

Tersedia Online : 31 Desember 2018

\begin{abstract}
Abstrak: Urbanisasi telah membawa perubahan-perubahan cepat dan mengubah banyak aspek dalam proses-proses perkotaan di banyak negara berkembang, termasuk dalam aspek spasial, khususnya dalam proses pembentukan formasi perkotaan yang melebar hingga ke kawasan-kawasan di sekitarnya, baik untuk memenuhi kebutuhan-kebutuhan ekonomi dalam proses produksi maupun untuk kebutuhan-kebutuhan sosial dan konsumsi kotanya. Dengan menggunakan kasus Metropolitan Surakarta, penelitian ini bertujuan untuk meningkatkan pemahaman terhadap proses spasial dari pertambahan penduduk perkotaan di wilayah pinggiran dari metropolitan sekunder yang berbasis pada kota menengah di Pulau Jawa, yang terkategori sebagai salah satu kawasan terpadat di dunia. Penelitian ini akan memperlihatkan proses metropolitanisasi dari Metropolitan Surakarta, sebagai akibat dari terbatasnya wilayah administrasi dari kota intinya sehingga proses pertumbuhan perkotaannya melebar ke wilayah kabupaten-kabupaten di sekitarnya. Analisis dilakukan dengan metode analisis time series, dengan menggunakan data kependudukan hasil Sensus Penduduk Nasional dari tahun 1990 hingga 2010. Hasil penelitian menunjukkan bahwa proses urbanisasi di Surakarta menghasilkan suatu proses perkembangan perkotaan yang melebar dan juga terfragmentasi pada beberapa wilayah kabupaten di sekitarnya. Formasi spasial perkotaan yang terbentuk meliputi suatu kombinasi dari perkembangan yang merambat dari kawasan-kawasan perkotaan yang telah ada sebelumnya dan pembentukan pusat-pusat kawasan perkotaan baru yang terus berkembang untuk saling merapat antara satu dengan yang lain. Proses-proses ini perlu dipahami mengingat proses urbanisasi juga merupakan kontributor utama yang menentukan pola konsumsi dan pengalokasian sumber daya di kawasan metropolitan tersebut. Khusus untuk Indonesia, pemahaman terhadap proses-proses ini juga akan sangat bermanfaat bagi perumusan strategi-strategi kolaborasi wilayah dalam pengembangan urbanisasi yang berkelanjutan di masa depan.
\end{abstract}

\footnotetext{
${ }^{1}$ Korespondensi Penulis: Departemen Perencanaan Wilayah dan Kota, Universitas Diponegoro, Semarang, Indonesia email: fadjar_mardiansjah@yahoo.com
} 


\title{
216 Pertumbuhan Penduduk Perkotaan dan Perkembangan Pola Distribusinya ...
}

Kata Kunci: bentuk spasial; kota menengah; metropolitanisasi; Surakarta; urbanisasi

\begin{abstract}
Urbanization has brought rapid changes and transformations in many aspects of urban processes of many developing countries, including in spatial aspect, in the form of extended spatial formation of the cities into the surroundings, in order to meet the needs of economic and productive processes as well as those of social and consumption processes. Using the case of the growth of Surakarta Metropolitan, this paper aims to deepen understanding on the spatial process of urban population growth in the peripheries of secondary metropolitan that based on medium city size in Java, which is considered as one of the most densest populated in the world. The article will show the process of metropolitanization in Surakarta Metropolitan, in which influenced of its limitness of the administrative jurisdiction of the core area, the the growth extends into the surrounding areas. The analysis employs a time serial analysis by utilizing the national censuses population data from 1990 to 2010, The result shows that the urbanization process in Surakarta leads into a extended spatial form which also characterized by a fragmented phenomena. The spatial urban formation formed by such a process consist of a combination of some extensions of the previous urban areas and the formation of new urban centers that approached and merged one to each other in the long run. This process need to be understood as urbanization process is also a major contributors that shape the resource allocation and consumption of resources in the metropolitan and the surrounding areas. For Indonesia, the understanding of these processes will be very beneficial for the formulation of regional collaboration strategies in developing sustainable urbanization in the future.
\end{abstract}

Keywords: medium cities; metropolitanization; spatial form; Surakarta; urbanization

\section{Pendahuluan}

Urbanisasi merupakan suatu fenomena yang diakibatkan oleh terkonsentrasinya penduduk beserta aktivitasnya pada suatu wilayah/kawasan tertentu sehingga kepadatan kawasan tersebut lebih tinggi daripada kawasan-kawasan lain di sekitarnya (Sato \& Yamamoto, 2005). Merlin \& Choay (2005) juga menjelaskan bahwa terminologi urbanisasi memiliki dua makna yang berbeda. Pada makna yang pertama, yang paling sering digunakan, urbanisasi didefinisikan sebagai tindakan menciptakan kota yang sering diikuti dengan proses perluasan ruang kota, sedangkan pada makna yang kedua urbanisasi didefinisikan sebagai proses peningkatan konsentrasi penduduk di kota-kota atau daerah perkotaan (Merlin \& Choay, 2005).

Di masa awal perhatian dunia terhadap proses urbanisasi, Davis (1955) mengemukakan bahwa proses urbanisasi sangat dipengaruhi oleh pertumbuhan penduduk kota yang selanjutnya akan membawa pengaruh intensif ke dalam perubahan sosial di dalam masyarakatnya. Argumennya didasarkan pada pendapat Tisdale (1942) yang mengatakan bahwa "urbanisasi adalah proses peningkatan konsentrasi penduduk, yang dilanjutkan dengan dua cara, yaitu penggandaan titik atau tempat terjadinya konsentrasi dan peningkatan ukuran dari setiap konsentrasi penduduk yang ada". Dari argumen tersebut, Tisdale (1942) juga mengemukakan bahwa pertumbuhan penduduk di kawasankawasan perkotaan sangat berpengaruh kepada proses urbanisasi yang terjadi di suatu wilayah. Oleh karena itu, studi mengenai urbanisasi sangat erat kaitannya dengan proses peningkatan jumlah dan konsentrasi penduduk serta proses perkembangan kota. Satu hal yang penting untuk dicatat bahwa di dalam konteks ini konsep urbanisasi tidak hanya dipandang sebagai sebuah fenomena berkembangnya suatu kota, tetapi juga sebagai suatu fenomena regional yang memperlihatkan perkembangan kawasan-kawasan perkotaan di wilayah tersebut. Berdasarkan pemahaman ini, selanjutnya Davis (1955) mengemukakan istilah tingkat urbanisasi yang juga dipahami sebagai suatu rasio penduduk perkotaan 
dengan jumlah penduduk total di suatu wilayah, yang kemudian digunakan sebagai suatu ukuran tingkat urbanisasi (urbanziation level) dari suatu wilayah.

Berbekal pada pendapat Galor (2004), Sato \& Yamamoto (2005) mengatakan bahwa proses urbanisasi sangat berkaitan dengan proses pertumbuhan dan pengkonsentrasian penduduk pada kawasan-kawasan perkotaan tertentu. Pada masa awal proses urbanisasi biasanya ditandai dengan meningkatnya laju pertumbuhan penduduk yang kemudian biasanya diikuti oleh berkembangnya pertumbuhan ekonomi secara simultan dari proses urbanisasi tersebut, walaupun selanjutnya laju pertumbuhan penduduk tadi akan melambat pada masa-masa berikutnya. Dalam konteks ini, Williamson (1965) juga menjelaskan bahwa konsentrasi dan aglomerasi merupakan suatu hal yang sangat penting pada masamasa awal dari proses pertumbuhan dan urbanisasi, yaitu pada masa terbatasnya infrastruktur transportasi dan komunikasi serta adanya keterbatasan ketersediaan modal. Dalam kondisi seperti ini, efisiensi produksi menghendaki adanya pengkonsentrasian spasial. Namun, ketika layanan infrastruktur dan akumulasi modal manusia dan kapital meningkat akibat adanya konsentrasi dan aglomerasi tersebut, maka perluasan spasial menjadi solusi dari persoalan eksternalitas yang diakibatkan oleh kemacetan yang tejadi di pusat-pusat konsentrasi. Serupa dengan pendapat Fujita \& Thisse (2002) yang mengatakan bahwa aglomerasi selalu berjalan berdampingan dan kondusif terhadap pertumbuhan, Baldwin \& Martin (2003) mengatakan bahwa secara spasial, terutama pada suatu tingkat tertentu di dalam kebijakan ekonomi yang mengutamakan pertumbuhan, hubungan saling melengkapi (komplementer) antara aglomerasi dan pertumbuhan akan menciptakan "spillover" yang mendorong terjadinya ekstensifikasi/perluasan fisik dari aglomerasi perkotan yang ada. Ekstensifikasi ini memperluas konsentrasi spasial dari penduduk dan aktivitas perkotaan pada proses urbanisasi.

Pada kasus di banyak negara berkembang, proses urbanisasi memicu terjadinya proses dan perkembangan spasial yang kompleks (Buhaug \& Urdal, 2013), baik secara internal kota maupun eksternal. Perkembangan ini kemudian membawa perubahan di dalam konfigurasi spasial kota, dalam konteks organisasi spasial, pemanfaatan dan intensitas, serta hubungan, aliran dan keterkaitan antara bagian-bagian wilayah, baik secara internal kota yang terus berkembang maupun antara kota yang satu dan kota yang lainnya. Perkembangan spasial dari konsentrasi-konsentrasi perkotaan tersebut juga berimplikasi kepada suatu proses transformasi desa-kota, yaitu perubahan dari kawasan perdesaan menjadi kawasan perkotaan, baik yang berada di pinggiran dari suatu kawasan konsentrasi perkotaan yang memperluas kawasan perkotaan yang ada maupun pada kawasan-kawasan lain yang memicu muncul dan berkembangnya kawasan-kawasan perkotaan yang baru, baik dalam konteks lingkungan fisik, maupun juga dalam konteks sosial dan ekonomi.

Indonesia telah mengalami peningkatan penduduk perkotaan lebih dari dua kali lipat, dari 55,4 juta jiwa dengan proporsi hanya sekitar 30,9\% dari seluruh penduduk Indonesia di tahun 1990 menjadi 118,3 juta jiwa dengan proporsi sekitar 49,8\% di tahun 2010 (Mardiansjah, 2013). Di masa mendatang, jumlah penduduk perkotaan akan terus meningkat, dan mencapai lebih dari 200 juta jiwa dengan proporsi hampir $70 \%$ dari seluruh penduduk Indonesia di tahun 2035 (BPS, 2015). Dari hampir 63 juta penduduk perkotaan baru antara tahun 1990 hingga 2010 tersebut, lebih dari 40 juta di antaranya merupakan penduduk perkotaan baru yang terdapat di Pulau Jawa. Penduduk perkotaan di Pulau Jawa sekitar 38,3 juta jiwa di tahun 1990 menjadi 79,9 juta jiwa di tahun 2010. Angka-angka ini tidak saja memperlihatkan bahwa Pulau Jawa merupakan tempat terkonsentrasinya penduduk perkotaan Indonesia, tetapi juga mengindikasikan bahwa Pulau Jawa juga merupakan tempat terkonsentrasinya pertambahan penduduk perkotaan.

Secara spasial, pertumbuhan penduduk perkotaan tersebut tidak terkonsentrasi di suatu tempat tertentu, tetapi tersebar pada berbagai tempat terutama pada kawasankawasan perkotaan yang telah tumbuh dan berkembang. Analisis yang dilakukan pada pola urbanisasi di Pulau Jawa memperlihatkan bahwa pertumbuhan penduduk perkotaan di 


\section{Pertumbuhan Penduduk Perkotaan dan Perkembangan Pola Distribusinya ...}

Jawa mengarah kepada dua pola utama, yaitu: pertumbuhan penduduk perkotaan pada kawasan kota-kota besar berbasis pada kota-kota besar dan menengah, dan kedua adalah pertumbuhan perkotaan pada kota-kota kecil dan mikro (Mardiansjah, 2013). Namun, sebagian besar penelitian yang dilakukan dalam konteks perkembangan spasial dari metropolitan di Pulau Jawa cenderung memberi fokus kepada kawasan-kawasan metropolitan yang berbasis pada kota-kota besar seperti Jakarta dan Bandung. Namun demikian, fenomena metropolitanisasi di Pulau Jawa juga sudah berlangsung pada kawasan-kawasan yang berbasis pada kota-kota kecil dan menengah, yang juga memperlihatkan indikasi kuat terjadinya pergeseran konsentrasi pertumbuhan penduduk dan aktivitas dari kawasan-kawasan inti menuju kepada kawasan-kawasan pinggiran. Hingga saat ini masih belum banyak penelitian yang dilakukan pada kota-kota kecil dan menengah tersebut. Fahmi dkk (2014) telah membangun kontribusi dengan melakukan penelitian tersebut pada kawasan metropolitan yang berbasis pada Kota Cirebon, yang dapat dikategorikan sebagai kota yang relatif kecil. Sementara penelitian ini dilakukan untuk mencoba memberi kontribusi dengan melakukan analisis pada metropolitan yang berbasis pada kota menengah.

Penelitian ini bertujuan untuk membangun pemahaman mendalam tentang proses spasial dari pertumbuhan yang terjadi dalam proses urbanisasi dan metropolitanisasi yang terjadi pada suatu kawasan pinggiran dari sebuah kota menengah di Pulau Jawa, dengan menggunakan kasus yang terjadi di Kota Surakarta. Penelitian ini memberikan gambaran tentang bagaimana pola pertumbuhan penduduk perkotaan dan perkembangan pola distribusi spasialnya dari masa ke masa, terutama kawasan pinggiran dari sebuah metropolitan yang berkembang dari sebuah kota yang terkategori sebagai kota berukuran menengah di Pulau Jawa. Pemilihan kawasan metropolitan yang terbangun oleh kota menengah dilakukan karena sebagian besar analisis tentang urbanisasi dan metropolitanisasi di Indonesia terfokus kepada metropolitan besar, khususnya Metropolitan Jakarta (Dorodjatoen, 2009; Firman \& Fahmi, 2017; Wahyudi, Liu, \& Corcoran, 2018; Winarso, Hudalah, \& Firman, 2015) dan Metropolitan Bandung (Budiyantini \& Pratiwi, 2016; Dorodjatoen, 2009; Firman, 2009). Namun, sebagai kawasan hunian utama di Indonesia berdasarkan Survei Penduduk Antar Sensus tahun 2015 yang menampung 145 juta jiwa atau $56,8 \%$ dari seluruh total penduduk Indonesia, termasuk 90,8 juta jiwa atau $67 \%$ dari seluruh penduduk perkotaan Indonesia (BPS, 2015), Pulau Jawa tidak hanya memiliki metropolitan besar dan raksasa yang berbasis kepada kota-kota besar seperti Metropolitan Bandung dan Metropolitan Jakarta, tetapi juga memiliki beberapa metropolitan yang berukuran jauh lebih kecil, baik yang berbasis kepada kota sedang atau bahkan kota kecil. Dalam konteks ini, penelitian ini juga ingin memberikan kontribusi terhadap analisis urbanisasi dan metropolitanisasi yang dilakukan pada kawasan metropolitan sedang yang masih jarang dibahas di dalam diskursus urbanisasi dan metropolitanisasi di Indonesia.

Pemilihan kepada Kawasan Metropolitan Surakarta dilakukan karena tiga hal utama. Pertama karena karakter Kota Surakarta, dengan penduduknya yang sekitar 500 ribuan jiwa, masih dapat dikategorikan sebagai kota sedang-besar dalam konteks ukuran kota-kota di Indonesia. Kedua adalah karena wilayah administrasi Kota Surakarta yang terbatas yang mendorong terjadinya pertumbuhan perkotaan yang meluas ke wilayah-wilayah di sekitarnya. Ketiga karena banyaknya kabupaten yang menjadi wilayah pinggiran dari Kawasan Metropolitan Surakarta, yaitu enam kabupaten dengan lima kabupaten yang utama, yang terdiri dari tiga kabupaten yang berbatasan langsung yaitu Sukoharjo, Karanganyar dan Boyolali dan dua kabupaten yang tak berbatasan langsung yaitu Klaten dan Sragen.

Badshah (1996) menjelaskan bahwa masa depan dan keberlanjutan dari kawasankawasan perkotaan sangat dipengaruhi oleh seberapa dalam pemahaman terhadap fenomena perkembangan kota yang berlangsung, termasuk terhadap masalah-masalah 
yang ditimbulkan serta tantangannya (Devas \& Rakodi, 1993). Oleh karena itu, pemahaman terhadap proses dan dinamika urbanisasi, serta perkembangan penduduk dan aktivitas perkotaan, termasuk yang terbangun dari suatu kota menengah, merupakan salah satu pemahaman yang sangat penting untuk dilakukan, karena pola urbanisasi di Indonesia, khususnya di Pulau Jawa, selalu berkembang dengan pola yang meluas hingga ke kawasankawasan pinggiran kota yang biasanya memiliki wilayah pengelolaan yang berbeda daripada pengelolaan di kawasan intinya. Badshah (1996) menyatakan bahwa proses urbanisasi yang terjadi seperti ini tidak saja berpeluang menimbulkan urban misery atau kesengsaraan perkotaan, namun menurut Williamson (1965) juga berpeluang mendorong terjadinya ketidaksetaraan antarwilayah/kawasan.

\section{Metode Penelitian}

Penelitian yang membahas dan mendiskusikan pola pertumbuhan penduduk perkotaan dan perkembangan pola distribusi spasial di kawasan pinggiran dari suatu kawasan metropolitan yang berkembang dari suatu kota menengah ini menggunakan Kawasan Metropolitan Surakarta sebagai wilayah studi. Kawasan metropolitan ini terbentuk dari perkembangan penduduk dan aktivitas perkotaan di Kota Surakarta sebagai kawasan inti, yang berkembang melebar ke kawasan pinggiran di wilayah kabupatenkabupaten di sekitarnya, yaitu Sukoharjo, Karanganyar, Boyolali, Sragen dan Klaten. Analisis dilakukan dengan menggunakan metode time series dengan menggunakan data klasifikasi desa (desa-desa perkotaan) pada tahun 1990, 2000 dan 2010, beserta data penduduk yang dihasilkan oleh Badan Pusat Statistik (BPS) dari proses pelaksanaan Sensus Penduduk Nasional.

Analisis ini dilakukan untuk memahami pola perkembangan kawasan perkotaan di kawasan pinggiran metropolitan, sebagai salah satu faktor utama yang menentukan proses metropolitanisasi di kawasan tersebut, maka analisis awal yang dilakukan dengan melakukan identifikasi terhadap kawasan-kawasan perkotaan yang terbentuk pada tahun 1990, 2000 dan 2010. Kawasan-kawasan perkotaan yang dimaksud adalah kawasankawasan yang terbentuk dari pengelompokan (aglomerasi) desa-desa perkotaan yang ada di wilayah kabupaten. Selanjutnya, dengan berbasis kepada kawasan-kawasan perkotaan yang teridentifikasi pada ketiga poin waktu tersebut, dilakukan penghitungan jumlah penduduk perkotaan pada setiap kawasan perkotaan yang terbentuk, dengan menjumlahkan seluruh penduduk dari desa-desa perkotaan yang teraglomerasi menjadi kawasan-kawasan perkotaan. Pengamatan terhadap perkembangan desa-desa perkotaan beserta lokasi dan perkembangan jumlah penduduk, kemudian digunakan untuk mengamati perkembangan spasial kawasan perkotaan di kawasan pinggiran Metropolitan Surakarta pada penelitian ini.

\section{Hasil dan Pembahasan}

\section{Metropolitan Surakarta sebagai Kawasan Perkotaan yang Cepat Tumbuh}

Metropolitan Surakarta yang terletak di kawasan tengah dari Provinsi Jawa Tengah adalah kawasan metropolitan yang terbangun dari teraglomerasinya kawasan perkotaan Kota Surakarta sebagai kawasan inti, dengan kawasan-kawasan perkotaan lain yang berada di wilayah kabupaten-kabupaten di sekitarnya, yaitu Sukoharjo, Karanganyar, Boyolali, Klaten, Sragen dan Wonogiri. Tiga kabupaten pertama merupakan kabupaten-kabupaten yang memiliki kecamatan yang berbatasan langsung dengan kawasan inti, Kota Surakarta, sedangkan tiga kabupaten lainnya tidak berbatasan langsung walaupun memiliki kecamatan-kecamatan yang berjarak relatif dekat dari pusat Kota Surakarta, kecuali Kabupaten Wonogiri (Gambar 1). 


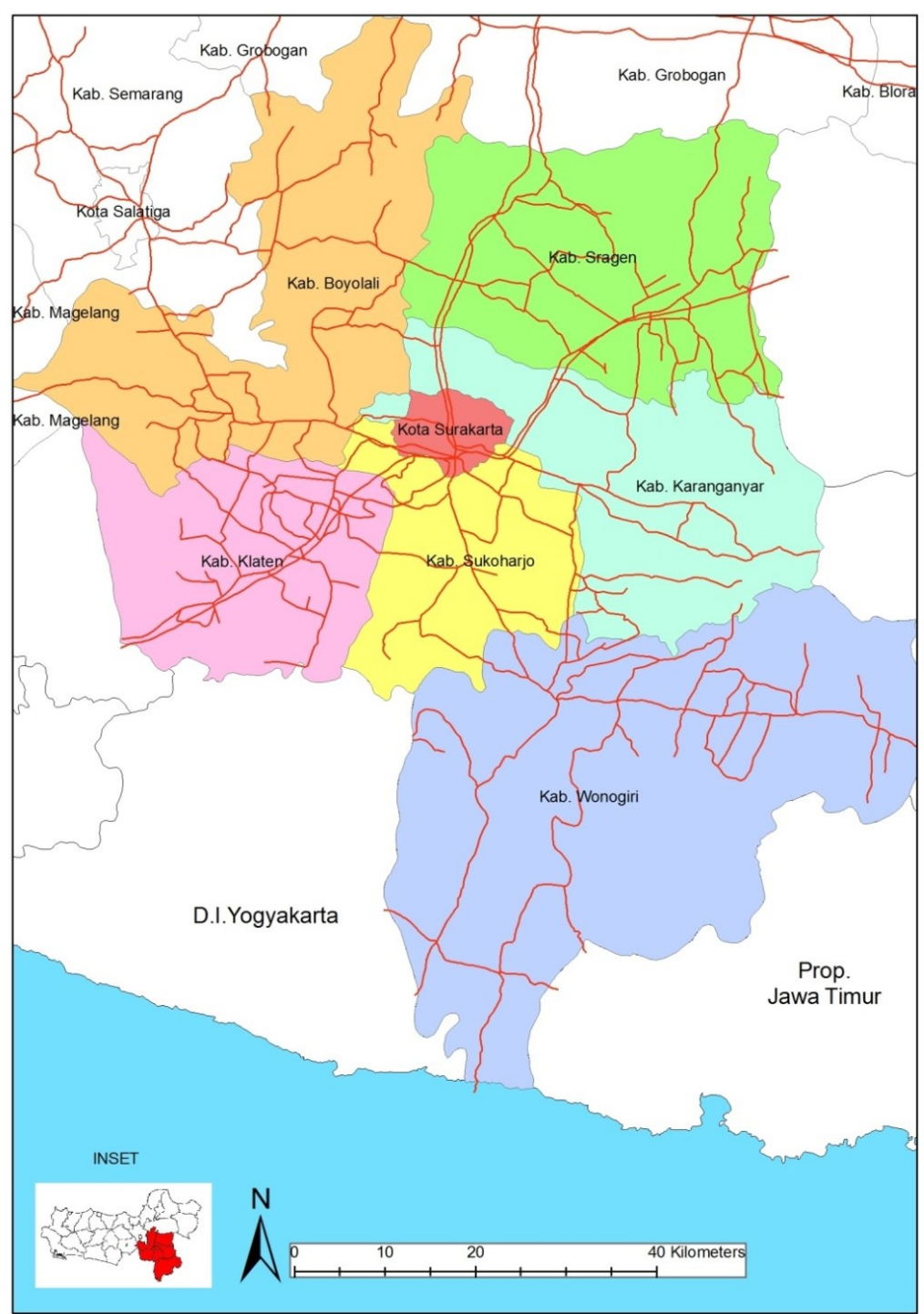

Sumber: Analisis Penulis, 2018

\section{Gambar 1. Wilayah Administrasi Metropolitan Surakarta}

Kabupaten Sukoharjo memiliki empat kecamatan yang berbatasan langsung dengan Kota Surakarta, yaitu Kartasura, Baki, Grogol dan Mojolaban, walaupun panjang kawasan perbatasan di Kecamatan Baki sangat pendek bila dibandingkan dengan ketiga kecamatan lainnya. Selain itu, Kabupaten Sukoharjo juga memiliki Kecamatan Gatak yang walaupun tak berbatasan langsung, namun memiliki jarak yang relatif dekat karena kurang dari tiga kilometer dengan batas Kota Surakarta. Sementara itu, Kabupaten Karanganyar memiliki tiga kecamatan yang berbatasan langsung dengan Kota Surakarta, yaitu Colomadu, Gondangrejo dan Jaten, sedangkan Kabupaten Boyolali hanya memiliki satu kecamatan yang berbatasan langsung, yaitu Kecamatan Ngemplak sebagai lokasi Bandara Adi Sumarmo.

Kabupaten Klaten dan Kabupaten Sragen memiliki keterhubungan (konektivitas) yang cukup kuat dengan Kota Surakarta, karena kedua kabupaten ini dihubungkan oleh keberadaan jaringan jalan nasional, walaupun tidak memiliki kecamatan yang berbatasan langsung dengan kawasan inti. Kabupaten Klaten dihubungkan dengan jaringan jalan nasional antara Surakarta-Yogyakarta, dan Kabupaten Sragen dihubungkan oleh jaringan 
jalan nasional Surakarta-Ngawi-Surabaya. Koneksi yang kuat juga dimiliki oleh Kabupaten Boyolali yang dihubungkan oleh jaringan jalan nasional yang menghubungkan Surakarta ke Semarang. Kondisi ini sangat berbeda dengan Kabupaten Wonogiri yang berjarak sangat jauh dari kawasan inti, juga tidak memiliki koneksi akses jalan sekuat Kabupaten Klaten dan Kabupaten Sragen.

Tabel 1. Pertumbuhan Penduduk Perkotaan di Kawasan Metropolitan Surakarta Tahun 1980-2010

\begin{tabular}{|c|c|c|c|c|c|c|c|c|}
\hline \multirow[t]{2}{*}{ Wilayah } & \multicolumn{4}{|c|}{ Jumlah Penduduk Perkotaan } & \multicolumn{2}{|c|}{$\begin{array}{l}\text { Proporsi } \\
\quad(\%)\end{array}$} & \multicolumn{2}{|c|}{$\begin{array}{c}\text { Laju } \\
\text { Pertumbuhan } \\
\text { Tahunan (\%) }\end{array}$} \\
\hline & 1980 & 1990 & 2000 & 2010 & 1980 & 2010 & $\begin{array}{c}\text { 1980- } \\
1990\end{array}$ & $\begin{array}{c}1980- \\
2010\end{array}$ \\
\hline Kota Surakarta & 469.532 & 504.176 & 490.214 & 500.642 & 43,6 & 16,2 & 0,74 & 0,22 \\
\hline Kawasan Inti & 469.532 & 504.176 & 490.214 & 500.642 & 43,6 & 16,2 & 0,74 & 0,22 \\
\hline Kab. Sukoharjo & 126.811 & 324.214 & 539.024 & 632.367 & 11,8 & 20,5 & 15,57 & 13,29 \\
\hline Kab. Karanganyar & 76.178 & 148.86 & 336.17 & 414.969 & 7,1 & 13,5 & 9,54 & 14,82 \\
\hline Kab. Boyolali & 42.623 & 128.494 & 235.307 & 306.09 & 4,0 & 9,9 & 20,15 & 20,60 \\
\hline Kab. Sragen & 56.985 & 70.621 & 233.474 & 277.31 & 5,3 & 9,0 & 2,39 & 12,89 \\
\hline Kab. Klaten & 268.805 & 384.896 & 714.535 & 759.45 & 24,9 & 24,6 & 4,32 & 6,08 \\
\hline Kab. Wonogiri & 36,607 & 108,852 & 164,143 & 190,450 & 3,4 & 6,2 & 19,74 & 14.01 \\
\hline Kaw. Pinggiran & 608.009 & 1.165 .937 & 2.222 .653 & 2.580 .636 & 56,4 & 83,8 & 9,18 & 10,81 \\
\hline Metro. Surakarta & 1.077.541 & 1.670.113 & 2.712.867 & 3.081.278 & 100,0 & 100,0 & 5,50 & 6,20 \\
\hline
\end{tabular}

Sumber: Dihitung berdasarkan data penduduk hasil sensus tahun 1980, 1990, 2000 dan 2010

Berdasarkan Sensus Penduduk Tahun 2010, Kota Surakarta yang berpenduduk 500.642 jiwa merupakan kota yang menempati urutan ke-27 berdasarkan jumlah penduduknya dari 94 kota di Indonesia, atau pada urutan ke-14 dari 30 kota di Pulau Jawa. Peringkat Kota Surakarta ini terus berkurang dari tahun ke tahun. Di tahun 1980, kota ini tercatat pada peringkat ke-10 dengan 469.888 penduduk, yang turun menjadi peringkat ke11 dengan 504.176 penduduk di tahun 1990, dan menjadi peringkat ke-19 dengan 488.843 penduduk di tahun 2000. Menurunnya peringkat Kota Surakarta dan juga penduduknya ini berkaitan dengan luas wilayah kota yang relatif sempit, yaitu sebesar $46.01 \mathrm{~km}^{2}$, sehingga lebih memberi dorongan untuk perkembangan perkotaan ke luar wilayah administrasi kota daripada ke dalam. Namun, apabila jumlah penduduk perkotaannya turut memperhitungkan yang berada pada kawasan perkotaan di luar wilayah administrasi Kota Surakarta, yaitu pada kawasan metropolitan atau urban region yang ada, diperkirakan Kawasan Metropolitan Surakarta merupakan kawasan perkotaan dengan urutan terbesar ke-7 berdasarkan jumlah penduduknya, dari seluruh kawasan perkotaan yang ada di Indonesia.

Sebagai salah satu kawasan utama tempat terkonsentrasinya penduduk dan aktivitas perkotaan, Kawasan Metropolitan Surakarta juga memiliki pertumbuhan penduduk perkotaan yang sangat cepat. Pada rentang waktu antara 1980-2010, metropolitan ini mengalami rata-rata pertumbuhan penduduk sebesar 6,20\% per tahun. Periode tahun 1990an merupakan periode pertumbuhan tertinggi dengan laju pertumbuhan 6,24\% per tahun setelah pertumbuhan 5,50\% per tahun pada dekade 1980-an. Hal yang menarik adalah bahwa pertumbuhan yang cepat tersebut tidak terjadi secara merata pada seluruh bagian kawasan metropolitan. Kota Surakarta sebagai kawasan inti dari metropolitan tersebut mengalami laju pertumbuhan yang sangat lambat sebesar $0,22 \%$ per tahun, sedangkan kawasan pinggiran mengalami pertumbuhan penduduk yang sangat cepat sebesar 10,81\% per tahun pada periode yang sama (lihat Tabel 1). Secara kewilayahan, laju pertumbuhan 
tercepat terjadi pada kawasan-kawasan perkotaan di Kabupaten Boyolali yang mengalami pertumbuhan yang sangat cepat sebesar 20,6\% per tahun. Pada Tabel 1 juga dapat dilihat bahwa Kabupaten Karanganyar dan Kabupaten Sukoharjo, yang memiliki kecamatankecamatan yang bersebelahan dengan Kota Surakarta, mengalami laju pertumbuhan penduduk yang sangat tinggi.

Pertumbuhan penduduk perkotaan yang sangat tinggi di kawasan pinggiran Kota Surakarta meningkatkan jumlah penduduk perkotaan metropolitan ini menjadi tiga kali lipat, dari 1,08 juta jiwa di tahun 1980 menjadi 3,08 juta jiwa di tahun 2010. Namun, dari pertambahan sekitar dua juta jiwa selama 30 tahun tersebut, kawasan inti (Kota Surakarta) hanya mengalami pertambahan 31.110 jiwa, sementara kawasan pinggiran mengalami pertambahan sebesar 1,97 juta jiwa dengan sebaran terbanyak yaitu 505,6 ribu jiwa terjadi pada kawasan-kawasan perkotaan di Kabupaten Sukoharjo yang memiliki lima buah kecamatan yang berbatasan langsung dengan Kota Surakarta. Kabupaten Karanganyar, yang juga memiliki kecamatan-kecamatan yang berbatasan langsung dengan Kota Surakarta juga mengalami pertambahan terbesar ketiga yaitu sekitar 338,8 ribu jiwa. Hal yang menarik terjadi di Kabupaten Klaten. Kabupaten Klaten tidak memiliki kecamatan yang berbatasan langsung tetapi mengalami pertambahan terbesar kedua yaitu sekitar 490,6 ribu jiwa.

Selain itu, pertumbuhan cepat dari kawasan metropolitan ini juga telah mengubah kawasan metropolitan yang masih memiliki tingkat urbanisasi sebesar 20,7\% di tahun 1980 menjadi sebuah kawasan yang sebagian besar penduduknya tinggal di kawasan-kawasan perkotaan sejak tahun 2000, dengan tingkat urbanisasi sebesar 52,3\% di tahun 2000, yang kemudian meningkat menjadi 51,5\% di tahun 2010. Pada tahun 2010, Kabupaten Sukoharjo adalah kabupaten yang memiliki tingkat urbanisasi tertinggi, yaitu sebesar $76,7 \%$, yang diikuti oleh Kabupaten Klaten dengan tingkat urbanisasi sebesar 67,2\%. Kabupaten Karanganyar juga telah memiliki tingkat urbanisasi tinggi sebesar $51 \%$, yang menunjukkan bahwa sebagian besar penduduknya telah terkategori sebagai masyarakat perkotaan sejak tahun 2010. Sementara Kabupaten Boyolali dan Kabupaten Sragen memiliki tingkat urbanisasi sebesar 32,9\% dan 32,3\%, yang mengindikasikan bahwa sebagian besar penduduk kedua kabupaten ini masih tergolong penduduk non-perkotaan.

Perkembangan pada kawasan metropolitan ini mengindikasikan terbentuknya kawasan metropolitan yang terfragmentasi di kawasan pinggirannya. Dengan menggunakan studi kasus Kawasan Metropolitan Jabodetabek, Wahyudi dkk (2018) memperlihatkan bahwa pertumbuhan kawasan perkotaan yang terfragmentasi ke kawasan pinggiran terutama terjadi dalam rangka mengakomodasi pertumbuhan penduduk perkotaan. Namun, pertumbuhan dan perkembangan kawasan perkotaan tidak terjadi secara merata di seluruh tempat, tetapi cenderung lebih terkonsentrasi pada kawasankawasan utama tertentu (Wahyudi dkk, 2018). Dalam konteks ini, perlu dianalisis dan dipahami proses dan pembentukan kawasan perkotaan yang terjadi pada Metropolitan Surakarta. Analisis ini akan memberikan pemahaman terhadap kecenderungan perkembangan kawasan-kawasan perkotaan yang berlangsung pada kawasan metropolitan ini, termasuk perkembangan kota-kota kecil yang terbentuk di kawasan pinggiran metropolitan ini di dalam proses metropolitanisasi yang berlangsung, sehingga strategistrategi pengelolaan pembangunan perkotaan di masa yang akan datang dapat dilakuan secara lebih baik.

\section{Perkembangan Kawasan Perkotaan pada Kawasan Metropolitan Surakarta}

Analisis perkembangan kawasan perkotaan pada Kawasan Metropolitan Surakarta ini dilakukan dengan mengamati tiga hal, yaitu perkembangan jumlah dan lokasi spasial dari desa-desa perkotaan yang ada di kawasan metropolitan tersebut, jumlah penduduk perkotaan yang terdapat di setiap wilayah, dan tingkat urbanisasi atau proporsi jumlah penduduk perkotaan yang terdapat di setiap wilayah terhadap jumlah penduduk totalnya. 


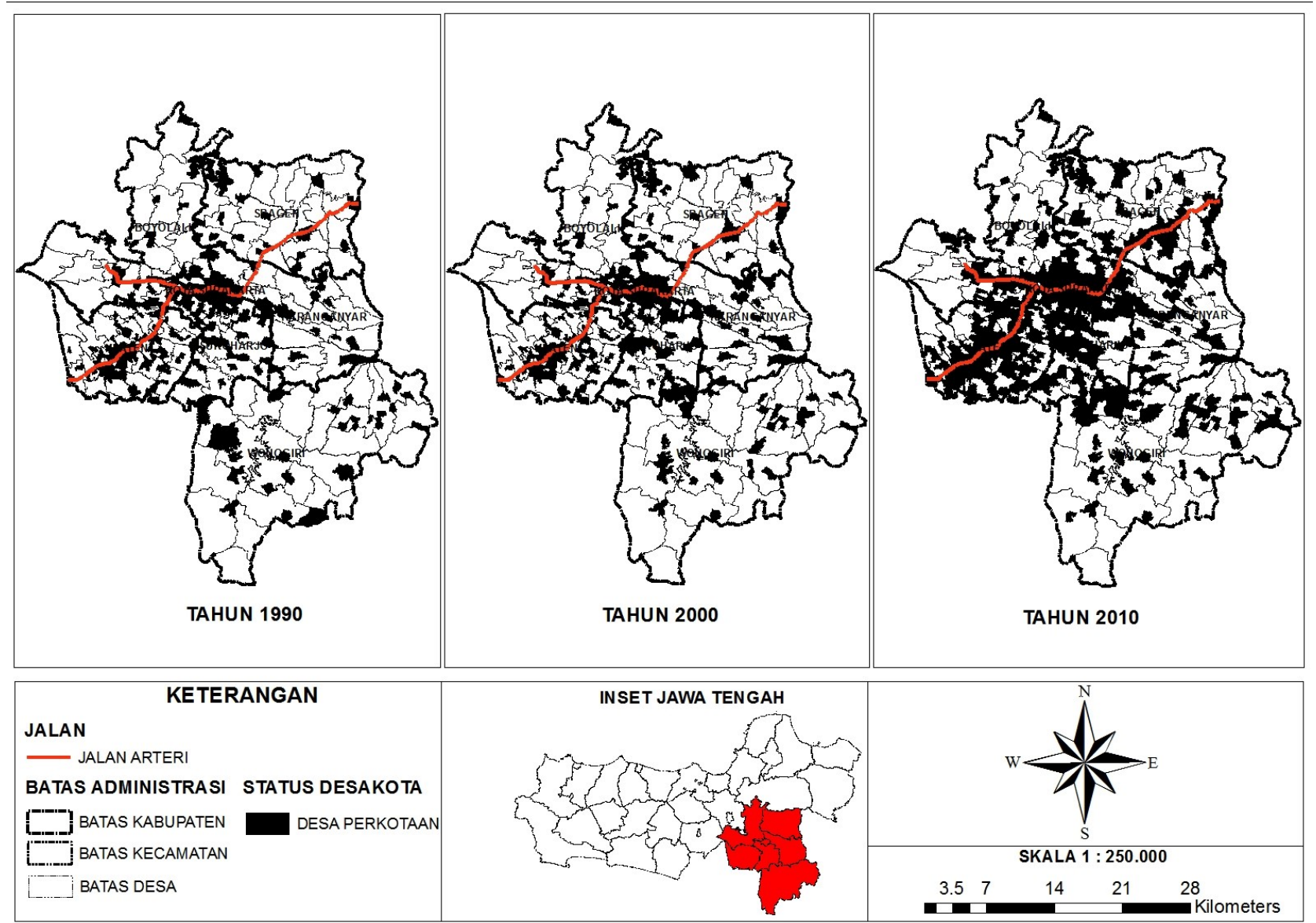

Sumber: Digambar ulang berdasarkan hasil analisis, 2018 


\section{Pertumbuhan Penduduk Perkotaan dan Perkembangan Pola Distribusinya .}

Data yang digunakan adalah data yang dihasilkan dari pengklasifikasian BPS terhadap seluruh desa dan kelurahan yang ada di tahun 1990, 2000 dan 2010, yang secara spasial lokasi dan penyebaran desa dan kelurahan perkotaan tersebut dapat dilihat pada Gambar 2. Pada gambar tersebut dapat dilihat Kota Surakarta merupakan pusat konsentrasi perkotaan pada kawasan metropolitan yang dikelilingi oleh keberadaan kawasan-kawasan perkotaan, yang dibangun oleh desa-desa perkotaan yang terus berkembang meluas dari waktu ke waktu.

Tabel 2. Tingkat Urbanisasi Wilayah di Kawasan Metropolitan Surakarta Tahun 1980-2010

\begin{tabular}{|c|c|c|c|c|c|c|c|c|}
\hline \multirow[b]{2}{*}{ Wilayah } & \multicolumn{4}{|c|}{ Tingkat Urbanisasi (\%) } & \multicolumn{4}{|c|}{ Pertambahan Tingkat Urbanisasi (\%) } \\
\hline & 1980 & 1990 & 2000 & 2010 & $\begin{array}{c}1980- \\
1990\end{array}$ & $\begin{array}{l}1990- \\
2000\end{array}$ & $\begin{array}{c}2000- \\
2010\end{array}$ & $\begin{array}{l}\text { 1980- } \\
2010\end{array}$ \\
\hline Kota Surakarta & 100.00 & 100.00 & 100.00 & 100.00 & 0.00 & 0.00 & 0.00 & 0.00 \\
\hline Kawasan Inti & 100.00 & 100.00 & 100.00 & 100.00 & 0.00 & 0.00 & 0.00 & 0.00 \\
\hline Kab. Sukoharjo & 21.26 & 48.19 & 69.53 & 76.72 & 26.92 & 21.35 & 7.19 & 55.46 \\
\hline Kab. Karanganyar & 12.60 & 21.33 & 44.31 & 51.03 & 8.73 & 22.98 & 6.72 & 38.43 \\
\hline Kab. Boyolali & 5.45 & 15.22 & 26.24 & 32.89 & 9.77 & 11.02 & 6.65 & 27.44 \\
\hline Kab. Sragen & 7.51 & 8.55 & 27.62 & 32.31 & 1.04 & 19.07 & 4.69 & 24.80 \\
\hline Kab. Klaten & 25.21 & 35.44 & 64.37 & 67.21 & 10.23 & 28.93 & 2.84 & 41.99 \\
\hline Kab. Wonogiri & 3.91 & 11.35 & 16.93 & 20.50 & 7.44 & 5.58 & 3.57 & 16.59 \\
\hline Kaw. Pinggiran & 12.82 & 22.93 & 41.50 & 47.05 & 10.11 & 18.58 & 5.54 & 34.23 \\
\hline Metro Surakarta & 20.67 & 29.88 & 46.41 & 51.48 & 9.20 & 16.53 & 5.07 & 30.80 \\
\hline
\end{tabular}

Sumber: Dihitung berdasarkan data Sensus Penduduk Tahun 1980, 1990, 2000 dan 2010.

Tabel 3. Pertumbuhan Desa Perkotaan di Metropolitan Surakarta Tahun 1990-2010

\begin{tabular}{lcccc}
\hline & \multicolumn{4}{c}{ Jumlah Desa/Kelurahan Perkotaan } \\
\cline { 2 - 5 } & $\mathbf{1 9 9 0}$ & $\mathbf{2 0 0 0}$ & $\mathbf{2 0 1 0}$ & Tambahan \\
\hline Kota Surakarta & 51 & 51 & 51 & 0 \\
Kabupaten Sukoharjo & 60 & 60 & 106 & 46 \\
Kabupaten Karanganyar & 23 & 38 & 63 & 40 \\
Kabupaten Boyolali & 30 & 31 & 74 & 44 \\
Kabupaten Sragen & 7 & 10 & 49 & 42 \\
Kabupaten Klaten & 115 & 115 & 252 & 137 \\
Kabupaten Wonogiri & 22 & 24 & 43 & 21 \\
\hline \multicolumn{1}{c}{ Total } & 311 & 329 & 638 & 327 \\
\hline
\end{tabular}

Sumber: Dihitung berdasarkan data Sensus Penduduk Tahun 1990, 2000 dan 2010

Analisis tentang perkembangan kawasan-kawasan perkotaan ini akan diklasifikasikan ke dalam tiga pembahasan, yaitu perkembangan awal yang merambat, perkembangan kawasan yang terpencar di masa awal, dan perkembangan selanjutnya dari kawasankawasan perkotaan di kawasan pinggiran Metropolitan Surakarta.

\section{Perkembangan Awal dari Kawasan Perkotaan yang Merambat}

Secara spasial, perkembangan desa-desa perkotaan di kawasan pinggiran Metropolitan Surakarta di masa lalu (hingga tahun 1990) cenderung lebih berada pada kawasan di sebelah selatan dari Kota Surakarta. Kawasan perkembangan desa-desa JURNAL WILAYAH DAN LINGKUNGAN, 6 (3), 215-233

http://dx.doi.org/10.14710/jwl.6.3.215-233 
perkotaan yang menjadi kawasan perambatan/perluasan/ekstensifikasi yang masif dari perkembangan penduduk dan aktivitas di kawasan perkotaan Kota Surakarta ini terjadi terutama di kecamatan-kecamatan bagian utara dari Kabupaten Sukoharjo yang berbatasan langsung dengan Kota Surakarta, seperti Grogol, Baki, Gatak, Mojolaban, dan termasuk di Kartasura yang terletak di sebelah barat kota. Masifnya perkembangan merambat di kawasan-kawasan perkotaan di kawasan pinggiran selatan ini ditunjang oleh keberadaan jaringan jalan arteri dan lokal yang menghubungkan wilayah kecamatan-kecamatan ini ke kawasan inti metropolitan yaitu wilayah Kota Surakarta, terutama wilayah Kecamatan Serengan, Kecamatan Pasar Kliwon dan Kecamatan Laweyan yang merupakan kawasankawasan utama di wilayah kota tersebut, sehingga kawasan-kawasan ini memiliki kemudahan yang kuat untuk menjangkau wilayah Kota Surakarta terutama kepada kawasan-kawasan utamanya. Pada masa ini, Kawasan Perkotaan Grogol dan Kartasura telah menjadi suatu kawasan perkotaan dengan masing-masing 63.902 dan 68.809 jiwa penduduk, sedangkan Mojolaban, Gatak dan Baki menjadi kawasan perkotaan dengan masing-masing 45.059, 34.643 dan 30.320 jiwa penduduk.

Kawasan ekstensifikasi di sebelah barat lainnya terjadi di Kecamatan Banyudono, Kabupaten Boyolali yang bersebelahan dengan Kecamatan Kartasura, Kabupaten Sukoharjo. Namun ekstensifikasi yang terjadi pada kawasan ini, di waktu itu, tidak terjadi secara masif seperti yang terjadi di sebelah selatan. Ini diindikasikan dari ukuran Kawasan Perkotaan Banyudono yang berpenduduk sebesar 18.853 jiwa. Hal serupa juga terjadi di kawasan sebelah timur yang berlokasi di Kecamatan Jaten (27.954 jiwa penduduk), dan juga pada kawasan sebelah utara di Kecamatan Gondangrejo (5.644 jiwa penduduk), yang keduanya merupakan bagian dari wilayah Kabupaten Karanganyar.

Sebagian besar aktivitas yang mendorong terjadinya ekstensifikasi ini adalah perkembangan aktivitas perumahan dan permukiman, baik yang dilakukan secara terencana dalam pembangunan kompleks-kompleks perumahan berskala besar maupun kombinasinya dengan pembangunan perumahan berskala yang jauh lebih kecil dan pembangunan spontan yang dilakukan secara individual, seperti yang terjadi di Kecamatan Jaten di Kabupaten Karanganyar, Kecamatan Baki, Kecamatan Gatak dan Kecamatan Mojolaban di Kabupaten Sukoharjo. Selain itu juga terdapat kombinasi perkembangan industri dan permukiman seperti yang terjadi di Kecamatan Kartasura dan Kecamatan Grogol di Kabupaten Sukoharjo. Dalam konteks kependudukan, perkembangan kawasan perumahan dan permukiman ini, terutama yang terkombinasi dengan kegiatan industri, memberikan dampak percepatan pertumbuhan penduduk yang cukup besar. Kondisi ini relatif berbeda dengan kawasan perluasan yang relatif hanya dipicu oleh aktivitas industri, seperti yang terjadi di Kecamatan Banyudono (Kabupaten Boyolali) dan Kecamatan Gondangrejo (Kabupaten Karanganyar), dengan perkembangan kawasan perkotaan yang terjadi tidak memberikan dorongan yang kuat kepada pertumbuhan penduduk seperti pada kawasan yang didorong oleh pembangunan perumahan dan permukiman.

\section{Perkembangan Kawasan Perkotaan Terpencar di Masa Awal}

Selain pola perkembangan yang merambat atau melebar ini, kawasan pinggiran Kawasan Metropolitan Surakarta juga memiliki perkembangan desa-desa perkotaan yang terpencar di banyak tempat. Suatu hal yang menarik adalah bahwa kecenderungan lokasi dari perkembangan desa-desa perkotaan yang terpencar di tahun 1990 ini serupa dengan kecenderungannya pada perkembangannya yang merambat, yaitu cenderung lebih berada di kawasan selatan dari kawasan pinggiran metropolitan ini, terutama di wilayah Kabupaten Sukoharjo dan Kabupaten Klaten. Kabupaten Sukoharjo merupakan wilayah yang paling terurbanisasi di masa lalu hingga tahun 1990, dengan jumlah penduduk perkotaan sebesar 324.214 jiwa dan tingkat urbanisasi $48,2 \%$ yang artinya bahwa jumlah penduduk perkotaan tersebut merupakan $48,2 \%$ dari jumlah seluruh penduduk totalnya. Selain memiliki kotakota kecamatan yang bekembang pada wilayah kecamatan-kecamatan yang berbatasan 
langsung dengan Kota Surakarta seperti yang telah dijelaskan sebelumnya, kabupaten ini juga memiliki kawasan perkotaan lain yang berkembang terpencar dari Kawasan Perkotaan Surakarta, yaitu Kawasan Perkotaan Sukoharjo yang berfungsi sebagai ibukota kabupaten dengan jumlah penduduk perkotaan sebesar 32.809 jiwa.

Sementara itu, Kabupaten Klaten merupakan wilayah kabupaten di kawasan pinggiran metropolitan ini dengan tingkat urbanisasi terbesar kedua dengan jumlah penduduk perkotaan yang lebih besar, yaitu 384.896 jiwa dan tingkat urbanisasi sebesar 35,4\%. Ibukota kabupaten ini, yaitu Kota Klaten, merupakan kawasan perkotaan kecil yang cukup besar, dengan penduduk sebesar 103.327 jiwa di tahun 1990, merupakan kawasan perkotaan terbesar yang berlokasi terpencar dalam Kawasan Metropolitan Surakarta ini. Selain itu, kabupaten ini juga memiliki 14 buah kota kecamatan lain yang berukuran antara 10.000-30.000 jiwa penduduk perkotaan di setiap kotanya, dan kawasan perkotaan lain yang lebih kecil.

Pada masa ini, hanya Kabupaten Klaten dan Kabupaten Sukoharjo yang memiliki tingkat urbanisasi yang relatif tinggi, sementara kabupaten-kabupaten lainnya masih memiliki tingkat urbanisasi yang relatif rendah, sehingga tingkat urbanisasi di kawasan metropolitan ini juga belum terlalu tinggi yaitu sekitar 29,9\% dan secara spasial kawasan perkotaan yang terbentuk relatif masih terpencar pada beberapa konsentrasi aglomerasi perkotaan, terutama pada wilayah Kabupaten Klaten, Kabupaten Sukoharjo dan Kabupaten Karanganyar. Umumnya perkembangan kawasan-kawasan perkotaan yang terpencar ini berasal dari perkembangan kawasan-kawasan perkotaan yang berasal dari ibukota kabupaten dan kota-kota kecamatan yang ada. Namun, hingga tahun 1990, tidak seluruh kecamatan di kawasan pinggiran Metropolitan Surakarta memiliki kawasan perkotaan yang telah berkembang. Kabupaten Sukoharjo yang memiliki tingkat urbanisasi tertinggi $(48,2 \%)$ di tahun 1990 (lihat Tabel 2) telah memiliki kawasan perkotaan di seluruh kecamatannya, walau tiga kecamatan di antaranya (Nguter, Bulu dan Tawangsari) hanya memiliki kawasan kecamatan yang masing-masing terbangun oleh hanya sebuah desa perkotaan sehingga masing-masing kawasan perkotaan tersebut masih memiliki jumlah penduduk yang sangat rendah di bawah 10.000 jiwa.

Kabupaten Klaten yang memiliki tingkat urbanisasi terbesar kedua di tahun 1990 $(35,4 \%)$ masih memiliki tiga buah kecamatan yang belum memiliki kawasan perkotaan, yaitu Gantiwarno, Manisrenggo dan Kemalang. Selain itu, kabupaten ini juga memiliki enam buah kecamatan lainnya (Jatinom, Wonosari, Prambanan, Kebonarum, Karangdowo, dan Karangnongko) yang masing-masing hanya memiliki satu hingga tiga desa perkotaan, sehingga jumlah penduduk perkotaan dari masing-masing kawasan perkotaan tersebut masih di bawah 10.000 jiwa. Kondisi serupa juga terjadi pada beberapa kecamatan di Kabupaten Karanganyar, Kabupaten Boyolali, Kabupaten Wonogiri dan Kabupaten Sragen yang masih memiliki tingkat urbanisasi yang sangat rendah di tahun tersebut.

\section{Perkembangan Selanjutnya dari Kawasan Perkotaan di Pinggiran Metroopolitan Surakarta}

Pada tahun 2000, tingkat urbanisasi kawasan metropolitan ini telah berkembang menjadi $46,4 \%$, dengan jumlah penduduk perkotaan sebesar 2,71 juta jiwa yang tersebar menjadi 0,49 juta di kawasan inti dan 2,22 juta di kawasan pinggiran. Tingkat urbanisasi di Kabupaten Sukoharjo dan Kabupaten Klaten masing-masing sebesar 69,5\% dan 64,4\%, dan tingkat urbanisasi Kabupaten Karanganyar juga telah berkembang menjadi 44,3\%, yang mengindikasikan bahwa kabupaten-kabupaten ini telah mengalami percepatan pada proses urbanisasinya pada dekade 1990-an. Namun, salah satu hal yang menarik adalah bahwa perkembangan spasial kawasan perkotaan yang terjadi hingga tahun 2000 ini tidak terlalu banyak berbeda dengan kondisinya di tahun 1990, yang artinya tidak terjadi banyak penambahan desa-desa perkotaan baru pada dekade 1990-an ini. Perubahan terbesar di tahun ini terjadi pada wilayah Kabupaten Karanganyar, terutama pada kecamatankecamatannya yang terletak bersebelahan dengan Kota Surakarta, yaitu di Jaten dan 
Colomadu; sementara Kabupaten Boyolali, Kabupaten Sragen dan Kabupaten Wonogiri hanya mengalami sedikit penambahan, bahkan Kabupaten Sukoharjo dan Kabupaten Klaten sama sekali tidak mengalami penambahan desa perkotaan di wilayahnya. Dengan demikian, proses urbanisasi yang terjadi pada wilayah kedua kabupaten ini pada dekade 1990-an relatif tidak melibatkan perubahan eksternal, melainkan hanya perubahan internal dari kawasan perkotaan yang terbangun dari wilayah desa-desa perkotaan yang telah tereklasifikasi sebelumnya.

Selanjutnya, proses urbanisasi yang sangat berbeda terjadi di kawasan metropolitan ini pada dekade tahun 2000-an. Proses urbanisasi yang terjadi pada periode 2000 -an ini terjadi dengan sangat ekstensif sehingga menciptakan 309 desa-desa perkotaan baru yang tersebar di seluruh kabupaten, seperti yang diperlihatkan pada Tabel 3, dengan pertambahan terbesar terjadi pada Kabupaten Klaten (137 buah desa perkotaan baru). Jumlah tersebut merupakan $44 \%$ dari jumlah desa perkotaan baru yang ada di kawasan metropolitan ini pada rentang waktu yang sama. Sementara itu, Kabupaten Sukoharjo, Kabupaten Karanganyar, Kabupaten Boyolali dan Kabupaten Sragen mengalami pertambahan dengan masing-masing memperoleh 46, 40, 44 dan 42 buah desa perkotaan baru yang sebagian besar diperoleh pada dekade tahun 2000-an.

Akibatnya, proses urbanisasi ini menghasilkan formasi spasial kawasan-kawasan perkotaan yang sangat berbeda di tahun 2010. Perkembangan tersebut "mengisi" banyak "kantong-kantong" kawasan non-perkotaan di sekitar kawasan-kawasan perkotaan yang ada sebelumnya (lihat peta tahun 2010 pada Gambar 2). Hasilnya, kawasan-kawasan perkotaan yang berada di kawasan pinggiran Metropolitan Surakarta, terutama pada kawasan pinggiran selatan, barat dan timur, meluas dan berkembang secara lebih ekstensif daripada yang terjadi pada dekade sebelumnya, yang selanjutnya berdampak kepada perluasan kawasan perkotaan di Kawasan Metropolitan Surakarta itu sendiri, dengan pola perkembangan sprawl yang sangat kuat yang terjadi di wilayah Kabupaten Klaten.

\section{Pola Spasial Perkembangan Kawasan Perkotaan Metropolitan Surakarta}

Secara spasial, perkembangan penduduk dan kawasan perkotaan di Metropolitan Surakarta pada periode 1990 hingga 2010 berkembang secara lebih kuat ke arah selatan, terutama ke barat daya ke wilayah Kabupaten Klaten dan ke arah selatan ke wilayah Kabupaten Sukoharjo (lihat Gambar 2). Perkembangan desa-desa perkotaan ke arah selatan ini cenderung masif ke banyak tempat yang tidak hanya sekedar berkembang di sepanjang koridor jalan regional yang ada, tetapi juga ke kawasan-kawasan yang relatif jauh dari koridor jalan regional tersebut. Perkembangan ke arah selatan ini terjadi dengan kondisi yang sangat berbeda dengan perkembangan ke arah lain, yaitu ke arah barat ke wilayah Kabupaten Boyolali, dan ke arah utara dan timur ke wilayah Kabupaten Sragen dan Kabupaten Karanganyar, yang cenderung masih merambat di sekitar kecamatankecamatan perbatasan yang terkombinasi dengan perkembangan yang bersifat memanjang pada jaringan jalan regional yang ada.

Pada dasarnya, proses urbanisasi yang terjadi di wilayah Kabupaten Klaten terjadi sangat berbeda apabila dibandingkan dengan proses yang terjadi pada kabupatenkabupaten lain. Perbedaan ini disebabkan oleh posisi kabupaten ini yang berada di antara dua buah kota utama di kawasan tengah Pulau Jawa, yaitu Kota Surakarta yang berpenduduk sekitar 500 ribuan jiwa hanya pada wilayah administrasi kotanya saja (yang berkembang dari sekitar 600 ribu jiwa di tahun 1980 menjadi sekitar 2,5 juta jiwa di tahun 2010 pada kawasan metropolitannya); dan Kota Yogyakarta yang berpenduduk sekitar 400 ribuan jiwa hanya pada wilayah administrasi kotanya (yang berkembang dari sekitar 500 ribu jiwa di tahun 1980 menjadi sekitar 2 juta jiwa di tahun 2010 pada kawasan metropolitannya), yang hanya berjarak sekitar $65 \mathrm{~km}$ dan dihubungkan dengan sebuah jalan nasional. Selain itu, kabupaten ini juga memiliki kondisi lanskap yang relatif datar yang dilengkapi oleh keberadaan jaringan jalan provinsi yang menghubungkan ibukota 
Kabupaten Klaten dengan ibukota Kabupaten Boyolali. Posisi serta keberadaan jaringanjaringan jalan regional tersebut memberi pengaruh dorongan yang kuat kepada proses pertumbuhan penduduk di wilayah ini, sehingga proses urbanisasi dan perkembangan kawasan-kawasan perkotaannya juga terjadi lebih cepat daripada yang terjadi di kabupaten-kabupaten lain. Hal ini diperlihatkan dari besarnya jumlah desa-desa di wilayah kabupaten ini yang telah terklasifikasi menjadi desa perkotaan sejak tahun 1990, terutama yang berlokasi di koridor jaringan-jaringan jalan regional yang ada.

Sementara itu, perkembangan urbanisasi yang terjadi di wilayah Kabupaten Sukoharjo sangat dipengaruhi oleh terjadinya pembangunan kegiatan industri besar dan sedang dan pembangunan sebuah kawasan kota baru (Solo Baru) yang dilakukan di Kabupaten Sukoharjo ini. Pada akhir 1980-an hingga awal 1990-an, PT Sri Rejeki Iman (Sritex), salah satu industri tekstil dan garmen utama di kawasan ini, melakukan pemindahan pabrik-pabriknya dari Kecamatan Laweyan, Kota Surakarta, ke Kecamatan Sukoharjo yang berjarak kurang dari $15 \mathrm{~km}$ dari Kota Surakarta. Selanjutnya di awal tahun 1990-an, berkembang kegiatan-kegiatan industri terutama industri tekstil dan garmen, industri furnitur dan industri plastik dan kimia di wilayah Kecamatan Grogol di kabupaten ini yang diiringi oleh pembangunan sebuah kota satelit baru, yaitu Solo Baru oleh PT Pondok Solo Permai, pada suatu kawasan seluas 200 ha di wilayah Kecamatan Grogol, yang berjarak sekitar $10 \mathrm{~km}$ dari pusat kota Surakarta. Selain juga menarik banyak penduduk untuk pindah dan bertempat tinggal di wilayahnya, pembangunan kota baru dan kegiatan industri ini, kemudian juga mendorong pembangunan banyak kawasan permukiman menengah dan rendah di sekitarnya, terutama di Kecamatan Baki hingga Kecamatan Gatak.

Suatu hal yang menarik adalah walapun tidak terjadi secara masif seperti di wilayah Kabupaten Klaten dan Kabupaten Sukoharjo, namun perkembangan kawasan perkotaan ekstensif juga terjadi pada kabupaten-kabupaten lainnya seperti Boyolali, Sragen dan Karanganyar (lihat Gambar 2). Ketersediaan jaringan jalan nasional yang menghubungkan Kota Surakarta dengan ibukota kabupaten-kabupaten ini memberi peluang pengembangan kegiatan industri pada beberapa kecamatan di kabupaten ini, seperti di Kecamatan Banyudono dan Kecamatan Teras di Kabupaten Boyolali, Kecamatan Jaten dan Kecamatan Kebakkramat di Kabupaten Karanganyar, dan Kecamatan Masaran dan Kecamatan Sidoharjo di Kabupaten Sragen, dengan intensitas perkembangan yang paling kuat terjadi di Kecamatan Jaten, yang bersebelahan dengan Kota Surakarta di sebelah timur. Perkembangan industri yang terjadi di Kecamatan Jaten berlangsung secara mengelompok terutama pada beberapa desa seperti Desa Ngringo (bersebelahan dengan pembangunan perumahan nasional yang dikembangkan pada periode sebelumnya), Desa Dagen dan Desa Jetis, dengan pengembangan ke Desa Brujul dan Desa Sroyo. Sementara itu, pembangunan kegiatan industri di kecamatan-kecamatan lain lebih terpencar dan kurang terkonsentrasi, seperti pada Kecamatan Jaten. Salah satu implikasi dari kondisi ini adalah bahwa perkembangan urbanisasi serta penduduk dan aktivitas perkotaan di kecamatan-kecamatan ini cenderung lambat, kecuali di Kecamatan Jaten dan Kecamatan Karanganyar.

Lebih lambatnya proses urbanisasi dan perkembangan ke arah timur, barat dan utara ini juga dipengaruhi oleh relatif jauhnya pusat-pusat perkotaan besar ke arah-arah tersebut yang terbangun dari ibukota dari kabupaten-kabupaten tersebut, yaitu Kawasan Perkotaan Karanganyar, Sragen dan Boyolali. Masing-masing kawasan perkotaan tersebut berjarak sekitar $30 \mathrm{~km}$ di sebelah timur, timur laut dan barat dari Kota Surakarta. Kondisi ini berbeda dengan posisi Kawasan Perkotaan Sukoharjo (ibukota Kabupaten Sukoharjo) yang berjarak kurang dari $15 \mathrm{~km}$ dari Kota Surakarta, yang dengan pengembangan kegiatan industri di dalamnya serta di kawasan antaranya mampu memberikan gaya tarik yang mendorong proses urbanisasi yang terjadi di wilayah tersebut. Kondisi serupa terjadi di wilayah Kabupaten Wonogiri. Jauhnya posisi kabupaten ini dari kawasan inti, Kota Surakarta, serta tidak tersedianya jaringan jalan regional utama membuat tidak banyak berkembangnya 
aglomerasi perkotaan pada wilayah kabupaten ini. Akibatnya, proses urbanisasi yang berlangsung di kabupaten ini terjadi relatif lambat.

\section{Implikasi pada Pengelolaan Urbanisasi dan Pembangunan Perkotaan}

Proses urbanisasi yang terjadi di Kota Surakarta dan sekitarnya memperlihatkan bahwa proses urbanisasi yang terjadi tidak lagi hanya suatu proses urbanisasi yang berbasis kota saja. Lebih daripada itu, proses urbanisasi yang terjadi telah meningkat menjadi suatu proses wilayah, yang tidak saja mengubah kota tempat proses urbanisasi tersebut terjadi, namun juga membangun dan mengembangkan kota-kota kecil dan/atau kawasan-kawasan perkotaan lain yang tidak bersebelahan, bahkan berlokasi cukup jauh dari kawasan perkotaan utamanya, serupa dengan proses urbanisasi yang terjadi di kota-kota besar Indonesia seperti yang dijelaskan oleh Firman (2009). Kasus yang terjadi di Metropolitan Surakarta ini juga memperlihatkan bahwa fenomena urbanisasi dan metropolitanisasi tidak hanya terjadi pada kawasan kota-kota besar dan/atau megacities saja, tetapi juga terjadi di kota-kota yang berukuran jauh lebih kecil seperti pada kota menengah dan kota kecil (Firman, 2009, 2016a). Kawasan metropolitan dari kota-kota menengah dan kota-kota kecil juga telah menjadi tempat bagi pertumbuhan penduduk perkotaan karena jaraknya yang tidak terlampau jauh dari kawasan kota-kota intinya. Terlebih apabila lokasinya strategis dan didukung oleh kemudahan aksesibilitas transportasi. Sebagai akibatnya, kawasan pinggiran dari metropolitan mengalami perubahan fisik lingkungan dan perubahan pemanfaatan lahan yang meningkatkan penggunaan lahan terbangun (Firman, 2016b).

Terkait dengan tahapan proses urbanisasi yang dijelaskan oleh Antrop (2004), proses urbanisasi yang terjadi di wilayah Kota Surakarta dan sekitarnya telah memperlihatkan terjadinya tahapan kedua dari proses urbanisasi, yaitu proses suburbanisasi, yang diperlihatkan oleh terjadinya pertumbuhan penduduk yang sangat cepat di kawasan pinggiran, yang jauh lebih cepat dari kawasan intinya sebagai akibat dari melambatnya atau jenuhnya pertumbuhan di kawasan inti. Dengan kata lain, proses urbanisasi yang berbasis wilayah ini ditandai oleh terjadinya ekspansi atau ekstensifikasi kawasan perkotaan yang dibarengi oleh terjadinya fenomena perkembangan kawasan perkotaan yang tersebar (urban sprawI) di kawasan pinggiran, yang tidak hanya diakibatkan oleh lompatan aktivitas dari kawasan perkotaan utama ke kawasan pinggirannya, tetapi juga dikombinasikan oleh terjadinya pertumbuhan internal dari kawasan-kawasan perkotaan di kawasan pinggiran tersebut.

Fenomena pertumbuhan penduduk perkotaan ini juga memiliki implikasi kepada persoalan lingkungan dan persoalan sosial. Samat, Hasni, \& Elhadary (2011) dan Wu, Zhang, \& Shen (2011) mengatakan bahwa pertumbuhan kawasan perkotaan ke kawasan pinggiran menjadi penyebab utama dari hilangnya kawasan pertanian dan kawasan lingkungan alami, yang kemudian juga memberikan ancaman terhadap kondisi keanekaragaman hayati dan ancaman pengurangan produktivitas pertanian. Neumann et al. (2014) dan Chi (2010) juga berpendapat bahwa pertumbuhan penduduk perkotaan yang cepat juga dapat meningkatkan kerentanan masyarakat, terutama di dalam kondisi ketersediaan sumber daya yang terbatas, dan kerentanan masyarakat itu bisa terjadi karena diakibatkan oleh peningkatan kelangkaan air yang sehat dan aman (Falkenmark, 2013) dan kerawanan pangan dan berkurangnya ketersediaan ternak (Godber \& Wall, 2014).

Pertumbuhan penduduk perkotaan ke kawasan pinggiran ini merupakan salah satu faktor utama dari perubahan lanskap di banyak negara, yang menghasilkan beragam bentuk kawasan perkotaan, baik yang berbentuk kompak maupun yang tersebar (Salvati, Zambon, Chelli, \& Serra, 2018). Pola urbanisasi yang kompak biasanya dicirikan dengan konsentrasi permukiman yang terpusat dengan tingkat kepadatan penduduk yang tinggi, sedangkan pola urbanisasi tersebar umumnya terdeteksi ketika pertumbuhan penduduk cenderung ekspansif ke arah pinggiran kota dengan tingkat kepadatan yang rendah dan terkadang diiringi oleh penurunan populasi dari kota inti (Zitti, Ferrara, Perini, Carlucci, \& 
Salvati, 2015). Dalam proses urbanisasi yang tersebar seperti ini, seperti yang dijelaskan oleh Cohen (2004, 2006), peran kawasan-kawasan perkotaan dan/atau kota-kota kecil, yang tumbuh dan berkembang di dalam proses urbanisasi, menjadi semakin meningkat sebagai arena dari proses urbanisasi dan perkembangan penduduk dan aktivitas perkotaan.

Namun, fenomena urbanisasi dan metropolitanisasi yang terjadi pada Kawasan Metropolitan Surakarta ini memperlihatkan bahwa perkembangan kawasan perkotaan, baik yang merambat maupun secara tersebar (spraw), tidak terjadi ke seluruh arah dalam besaran yang serupa. Kawasan pinggiran dari metropolitan ini dilalui oleh jaringan jalan nasional ke arah barat ke wilayah Kabupaten Boyolali dan ke arah timur serta timur laut ke wilayah Kabupaten Karanganyar dan Kabupaten Sragen, namun perkembangan utama dari kawasan metropolitan ini berlangsung ke arah selatan ke wilayah Kabupaten Sukoharjo dan ke arah barat daya ke wilayah Kabupaten Klaten. Hal ini disebabkan oleh adanya pengaruh kota (pusat pertumbuhan/aktivitas lain) yang memiliki jarak yang cukup baik untuk mendorong terjadinya pertumbuhan. Dalam konteks ini, fenomena pertumbuhan kawasan perkotaan lebih dominan ke wilayah Klaten di masa lalu, yaitu pada masa sebelum tahun 1990, memperlihatkan bahwa keberadaan pusat pertumbuhan/aktivitas lain ini memberi pengaruh yang lebih signifikan daripada ketersediaan akses jaringan jalan yang baik. Kondisi ini juga ditunjukkan oleh fenomena perkembangan ke arah selatan ke wilayah Kabupaten Sukoharjo yang kemudian mendominasi pada masa pasca tahun 1990-an. Implikasinya pola perubahan kawasan beserta penggunaan lahan yang terjadi relatif berbeda daripada menghasilkan pola perubahan yang melingkar, seperti yang sering terjadi pada proses urbanisasi di kota-kota di Eropa (Antrop, 2004). Pola perubahan lahan dan kawasan yang terjadi di kawasan pinggiran di Metropolitan Surakarta ini cenderung berupa setengah melingkar (half-ring development).

Jaegen, Bertiller, Schwick, Cavens, \& Kienast (2010) mengemukakan bahwa pertumbuhan kawasan perkotaan yang menyebar dengan pola kepadatan rendah sebagai suatu pola pertumbuhan perkotaan yang tidak efisien. Proses ini juga memiliki sejumlah implikasi yang merugikan ketika perluasan lahan perkotaan tidak terjadi secara berkelanjutan, dengan memangsa lahan-lahan pertanian subur penghasil pangan, hutan dan lahan alami lainnya yang mereduksi kesehatan ekosistem setempat serta memicu konflikkonflik lingkungan serta masalah-masalah sosial sehingga meningkatkan kerentanan wilayah dan penduduknya dan mempengaruhi kesejahteraan penduduk di masa yang akan datang (Costanza et al., 2014).

Dalam konteks pengelolaan urbanisasi dan/atau pengelolaan pembangunan perkotaan, pertumbuhan kawasan perkotaan yang melebar dan tersebar ke wilayah lain ini membutuhkan perhatian yang lebih kuat, karena pada dasarnya pertumbuhan perkotaan saat ini tidak lagi hanya merupakan proses pertumbuhan yang terjadi di daerah-daerah kota saja, melainkan juga di daerah-daerah kabupaten. Banyak kabupaten memiliki jumlah penduduk perkotaan yang lebih tinggi daripada jumlah penduduk yang dimiliki oleh daerah kota kawasan intinya, dalam kondisi yang tersebar ke dalam banyak atau beberapa kawasan perkotaan yang berada di wilayahnya. Oleh karena itu, pengembangan kapasitas pengelolaan pembangunan perkotaan pada daerah-daerah kabupaten seperti ini juga harus ditingkatkan. Selain itu, pengembangan instrumen dan kapasitas kerja sama pembangunan juga harus dikembangkan pada daerah-daerah kabupaten dan kota yang mengalami proses pertumbuhan urbanisasi dan metropolitanisasi seperti ini, karena pola pertumbuhan urbanisasi yang terfragmentasi ke dalam beberapa wilayah kabupaten dan kota seperti yang telah didiskusikan di dalam penelitian ini.

\section{Kesimpulan}

Analisis yang dilakukan memperlihatkan bahwa metropolitan sedang seperti Metropolitan Surakarta juga memiliki dinamika pertumbuhan yang cepat dan kompleks. 
Kawasan metropolitan ini mengalami pertumbuhan penduduk perkotaan yang cepat yang meningkatkan jumlahnya hingga menjadi tiga kali lipat selama tiga puluh tahun antara tahun 1980 hingga 2010. Pola urbanisasi dan pertumbuhan penduduk yang terjadi memperlihatkan pola yang melebar ke kawasan pinggiran, dengan pertumbuhan penduduk perkotaan di kawasan pinggiran berlangsung secara jauh lebih cepat daripada pertumbuhannya di kawasan inti yang terjadi secara stagnan. Diperkirakan, stagnasi yang terjadi di kawasan inti tersebut diakibatkan oleh terbatasnya lahan potensial bagi perkembangan kota di dalam wilayah administrasi dari kawasan inti, yang juga terkombinasi oleh tersedianya secara luas lahan potensial perkembangan kota di kawasan pinggiran yang didukung oleh ketersediaan jaringan jalan regional yang menghubungkan kawasan-kawasan pinggiran tersebut dengan pusat-pusat aktivitas di kawasan inti.

Pola pertumbuhan cepat yang melebar ke kawasan pinggiran ini memperlihatkan dinamika pertumbuhan yang berbeda di antara satu kawasan pinggiran dengan kawasan pinggiran lainnya. Perbedaan orientasi arah pertumbuhan juga terjadi pada dinamika waktu yang berbeda. Pertumbuhan yang terjadi di kawasan pinggiran Metropolitan Surakarta, yang memiliki ketersediaan jaringan jalan regional ke seluruh arah utara, selatan, barat dan timur, cenderung terkonsentrasi mengarah ke beberapa arah tertentu dengan dominasi utama, pada awalnya ke arah selatan dan barat daya ke wilayah Kabupaten Sukoharjo dan Kabupaten Klaten. Pada masa berikutnya, kecenderungan arah pertumbuhan berkembang dengan variasi pertumbuhan ke arah timur, dan pada periode terakhir juga mulai terjadi ke arah utara. Pertumbuhan cepat ke pinggiran ini tidak saja dipengaruhi oleh ketersediaan jaringan jalan regional yang ada, tetapi juga sangat dipengaruhi oleh keberadaan pusatpusat konsentrasi penduduk dan aktivitas dalam jarak yang tidak terlalu jauh, yang telah ada sebelumnya. Aglomerasi kawasan konsentrasi pertumbuhan yang telah ada sebelumnya tersebut memberikan daya tarik pertumbuhan pada masa sesudahnya.

Pola urbanisasi yang melebar ini juga telah meningkatkan peran kawasan pinggiran sebagai tempat berlangsungnya konsentrasi penduduk dan aktivitas perkotaan di Kawasan Metropolitan Surakarta ini. Hal ini diperlihatkan oleh tumbuh-berkembangnya konsentrasikonsentrasi baru di kawasan pinggiran, baik dari pusat-pusat konsentrasi penduduk yang telah ada sebelumnya maupun yang baru tercipta di dalam proses urbanisasi dan metropolitanisasi yang terjadi. Akibatnya, pertumbuhan di kawasan pinggiran ini membawa pengaruh terhadap perkembangan struktur metropolitan, dari yang relatif berpusat tunggal di masa lalu menjadi sebuah kawasan metropolitan yang memiliki tiga buah kawasankawasan pusat konsentrasi penduduk dan aktivitas perkotaan di kawasan pinggiran yang tumbuh dan berkembang, yang juga memiliki tendensi yang juga terus meluas sehingga mengubah kondisi lingkungan yang terdapat di kawasan pinggiran.

Dalam konteks urbanisasi dan metropolitanisasi, penelitian ini memberikan paparan yang mendukung kepada argumen tentang pentingnya perluasan perhatian dan pengelolaan kepada kawasan-kawasan metropolitan yang tumbuh dan berkembang. Perhatian yang harus diberikan tidak saja cukup kepada metropolitan-metropolitan besar dan raksasa yang telah ada, tetapi juga perlu dikembangkan kepada metropolitanmetropolitan lain yang berukuran jauh lebih kecil, seperti Kawasan Metropolitan Surakarta ini. Dinamika pertumbuhan cepat dan kompleks yang terjadi pada metropolitan yang berukuran sedang seperti ini juga membutuhkan pengelolaan tepat dalam konteks perumusan strategi metropolitan yang baik. Tidak tersedianya strategi metropolitan yang baik akan membuka peluang terjadinya pertumbuhan yang tidak terkontrol di kawasan pinggiran.

Dari sisi pengelolaan, pertumbuhan dan perkembangan kawasan metropolitan ini membawa tantangan yang besar, karena perkembangan kawasan metropolitan yang terfragmentasi ke dalam beberapa wilayah pengelolaan yang berbeda, terutama ke wilayah kabupaten yang selama ini masih dipersepsikan sebagai wilayah non-perkotaan. Dalam konteks ini, proses urbanisasi yang terjadi di Kota Surakarta juga membawa implikasi 


\section{Pertumbuhan Penduduk Perkotaan dan Perkembangan Pola Distribusinya...}

kepada beberapa kabupaten untuk mampu melakukan pengelolaan pembangunan perkotaan, sebagaimana sebagian besar penduduknya telah bertempat tinggal di kawasankawasan perkotaan yang ada di wilayahnya.

\section{Ucapan Terima Kasih}

Ucapan terima kasih disampaikan kepada Direktorat Penelitian dan Pengabdian kepada Masyarakat (Ditlitabmas), Direktorat Jenderal Pendidikan Tinggi (Ditjen Dikti), Kementerian Pendidikan dan Kebudayaan, yang telah membiayai penelitian ini melalui Daftar Isian Pelaksanaan Anggaran (DIPA) Direktorat Penelitian dan Pengabdian kepada Masyarakat, Nomor DIPA-023.04.1.673453/2015, tanggal 14 November 2014, DIPA Revisi 01 tanggal 03 Maret 2015, dengan Surat Penugasan Pelaksanaan Penelitian Hibah Fundamental sumber Dana Ditlitabmas Ditjen Dikti Kemendikbud Tahun Anggaran 2015 Nomor: 140-19/UN7.5.1/PG/2015.

\section{Daftar Pustaka}

Antrop, M. (2004). Landscape change and the urbanization process in Europe. Landcape and Urban Planning, 67, 9-26. doi:10.1016/S0169-2046(03)00026-4.

Badan Pusat Statistik (BPS). (2015). Penduduk Indonesia: Hasil survei penduduk antar sensus 2015. Badan Pusat Statistik Indonesia.

Badshah, A. A. (1996). Our urban future: New paradigms for equity and sustainability. London and New Jersey: Zed Books Ltd.

Baldwin, R., \& Martin, P. (2003). Agglomeration and regional growth. Handbook of Regional and Urban Economics, 4(3960), 2671-2711. doi:10.1016/S1574-0080(04)80017-8.

Budiyantini, Y., \& Pratiwi, V. (2016). Peri-urban typology of Bandung Metropolitan Area. Procedia - Social and Behavioral Sciences, 227(November 2015), 833-837. doi:10.1016/j.sbspro.2016.06.152.

Buhaug, H., \& Urdal, H. (2013). An urbanization bomb? Population growth and social disorder in cities. Global Environmental Change, 23, 1-10. doi:10.1016/j.gloenvcha.2012.10.016.

Chi, G. (2010). Land Developability: Developing an index of land use and development for population research Guangqing. Journal of Maps, 6(1), 609-617. doi:10.4113/jom.2010.1146.

Cohen, B. (2004). Urban growth in developing countries: A review of current trends and a caution regarding existing forecasts. World Development, 32(1), 23-51. doi:10.1016/j.worlddev.2003.04.008.

Cohen, B. (2006). Urbanization in developing countries: Current trends, future projections, and key challenges for sustainability. Technology in Society, 28, 63-80. doi:10.1016/j.techsoc.2005.10.005.

Costanza, R., de Groot, R., Sutton, P., van der Ploeg, S., Anderson, S. J., Kubiszewski, I., ... Turner, R. K. (2014). Changes in the global value of ecosystem services. Global Environmental Change, 26, 152-158. doi:10.1016/j.gloenvcha.2014.04.002.

Davis, K. (1955). The origin and growth of urbanization in the world. World Urbanism, 60(5), 429-437.

Devas, N., \& Rakodi, C. (1993). The urban challenge. In N. Devas \& C. Rakodi (Eds.), Managing fast growing cities. New approaches to urban planning and management in the developing world (pp. 1-40). Essex, Longman House.

Dorodjatoen, A. M. H. (2009). The emergence of Jakarta-Bandung mega-urban region and its future challenges. Jurnal Perencanaan Wilayah Dan Kota, 20(1), 15-33.

Falkenmark, M. (2013). Growing water scarcity in agriculture: future challenge to global water security. Philosophical Transactions of The Royal Society. doi:10.1098/rsta.2012.0410.

Firman, T. (2009). The continuity and change in mega-urbanization in Indonesia: A survey of Jakarta-Bandung Region (JBR) development. Habitat International, 33(4), 327-339. doi:10.1016/j.habitatint.2008.08.005.

Firman, T. (2016a). Demographic patterns of Indonesia's urbanization, 2000-2010: Continuity and change at the macro level. In G. C \& J. G (Eds.), Contemporary demographic transformations in China, India and 
Indonesia. Demographic transformation and socio-economic development,. Springer, Cham. doi:10.1007/978-3-319-24783-0_16.

Firman, T. (2016b). The urbanisation of Java, 2000-2010: towards 'the island of mega-urban regions.' Asian Population Studies, 1-17. doi:10.1080/17441730.2016.1247587.

Firman, T., \& Fahmi, F. Z. (2017). The privatization of metropolitan Jakarta's (Jabodetabek) urban fringes: The early stages of "post-suburbanization" in Indonesia. Journal of the American Planning Association, 83(1), 68-79. doi:10.1080/01944363.2016.1249010.

Fujita, M., \& Thisse, J.-F. (2002). Economic agglomeration: Cities, industrial location, and regional growth. Cambridge: Cambridge University Press.

Godber, O. F., \& Wall, R. (2014). Livestock and food security: vulnerability to population growth and climate change. Global Change Biology, 20, 3092-3102. doi:10.1111/gcb.12589.

Jaegen, J. A. ., Bertiller, R., Schwick, C., Cavens, D., \& Kienast, F. (2010). Urban permeation of landscapes and sprawl per capita: New measures of urban sprawl. Ecological Indicators, 10, 427-441. doi:10.1016/j.ecolind.2009.07.010.

Mardiansjah, F. H. (2013). Urbanisation durable des territoires et politiques de développement urbain en Indonésie: Étude de trois kabupaten en voie d'urbanisation rapide dans lîle de Java. University of ParisEst.

Merlin, P., \& Choay, F. (2005). Dictionnaire de l'urbanisme et de l'aménagement. Paris: Quadrige/Manuel.

Neumann, J. E., Price, J., Chinowsky, P., Wright, L., Ludwig, L., Streeter, R., ... Martinich, J. (2014). Climate change risks to US infrastructure : impacts on roads, bridges, coastal development, and urban drainage. Climatic Change, 131(1), 97-109. doi:10.1007/s10584-013-1037-4.

Salvati, L., Zambon, I., Chelli, F. M., \& Serra, P. (2018). Do spatial patterns of urbanization and land consumption reflect different socioeconomic contexts in Europe? Science of the Total Environment, 625, 722-730. doi:10.1016/j.scitotenv.2017.12.341.

Samat, N., Hasni, R., \& Elhadary, Y. A. E. (2011). Modelling land use changes at the peri-urban areas using geographic information systems and cellular automata model. Journal of Sustainable Development, 4(6), 72-84. doi:10.5539/jsd.v4n6p72.

Sato, Y., \& Yamamoto, K. (2005). Population concentration, urbanization, and demographic transition. Journal of Urban Economics, 58, 45-61. doi:10.1016/j.jue.2005.01.004.

Tisdale, H. (1942). The process of urbanization. Social Forces, 20(3), 311-316. doi:10.2307/3005615.

Wahyudi, A., Liu, Y., \& Corcoran, J. (2018). Combining Landsat and landscape metrics to analyse large-scale urban land cover change: a case study in the Jakarta Metropolitan Area. Journal of Spatial Science, 1-20. doi:10.1080/14498596.2018.1443849.

Williamson, J. G. (1965). Regional inequality and the process of national development: A description of the patterns. Economic Development and Cultural Change, 13(4), 1-84. doi:10.1086/450136.

Winarso, H., Hudalah, D., \& Firman, T. (2015). Peri-urban transformation in the Jakarta metropolitan area. Habitat Intemational, 49, 221-229. doi:10.1016/j.habitatint.2015.05.024.

Wu, Y., Zhang, X., \& Shen, L. (2011). The impact of urbanization policy on land use change: A scenario analysis. Cities, 28(2), 147-159. doi:10.1016/j.cities.2010.11.002.

Zitti, M., Ferrara, C., Perini, L., Carlucci, M., \& Salvati, L. (2015). Long-term urban growth and land use efficiency in Southern Europe: Implications for sustainable land management. Sustainability, 7, 33593385. doi:10.3390/su7033359. 